\title{
GENDER, LABOR, AND EMOTION IN A GLOBAL ECONOMY
}

As our bus pulled away from the curb at the Atatürk International Airport in Istanbul, Olga explained that PanUkraine was one of the largest companies arranging package tours for shuttle traders traveling from Moscow to Istanbul. Looking around I saw that aside from the Russian-speaking Turkish guide at the front, all others en route with us to the Hotel Prestige were women in their late thirties to late forties; Olga described the passengers as "prepared to begin trading as soon as we arrived," and she laughed at the Russian-speaking guide's mistaken suggestion that the "girls" (devushki) were naive and should be careful in their transactions. Most traders, she surmised, were like her, and after initially feeling ashamed to be involved in trade, for nearly ten years they had made the trek to Istanbul on a monthly basis. Beginning in the early 1990s, the journeys to and from Istanbul became part of a broader transformation of intimate practices and affective states brought about by new forms of gendered mobility in the newly capitalist region.

Focusing on women shuttle traders who make frequent trips between Moscow and Istanbul, in this chapter I examine discourses on one type of emotion, shame, as well as its link to ideal gender roles and intimate practices among Russian women entrepreneurs. ${ }^{1}$ In a post-Soviet era increasingly shaped by transnational mobility, as well as by a persistent legacy of Soviet sensibilities and "emotion regimes" (Reddy 1999), women traders provide an ideal lens for thinking about what travels between eras marked by distinct ideologies, between nation-states, and between public and domestic spaces. Cultural practices, shared professional knowhow, and gender negotiations performed by this group of women are linked to a distinct 
postsocialist, and specifically post-Soviet, "transnational circuit" moving apparel into Russia, in this case from Turkey. ${ }^{2}$ Russian women's insertion into a global economy beginning in the 1990s has required emotion work that is framed by Soviet-influenced reflections on labor and contemporary politics of gender in Russia. Despite this distinct cultural formation, ultimately there are many parallels with the way emotion work is required in other contexts where global capitalism has transformed work lives and required people to renegotiate intimate practices intertwining gender, labor, and expressions of power (Hochschild 1983; Colen 1995).

My point of departure is the emotion of "shame" and, to a lesser degree, its twin, "honor." A focus on this pair helps distill the contradictory ways in which women are positioned within both the intimate practices of newly capitalist Russia and a global economy in the 2000s. Ultimately, attention to emotions furthers our understanding of shifting structures of power in the region and beyond, but I also turn attention to how emotion, something often seen as a personal state, is linked to a collective, structurally inflected affect (Ahmed 2004). Women entrepreneurs' accounts highlight anxieties about proper forms of labor but also about gender sensibilities, which tend to elevate men's roles as breadwinners even when the facts are otherwise. These specific anxieties map onto the cultural and political context of the former Soviet Union, and they also resonate with the implications that women's intensified transnational mobility has for configurations of power globally. Women entrepreneurs' frequent accounts of the shame they felt at first getting involved in trade compelled me to think about postsocialism and emotions, along with reflections on gendered labor, as a portal onto shifting intimate practices of individuals vis-à-vis state power.

Traders' accounts reflect the ways that a wide range of people were formerly invested in state-defined moral frameworks that shaped belonging in a Soviet era (Grant 1995; Humphrey and Mandel 2002; Wanner 2005). As traders have learned to be good capitalists, they have had to unlearn, or at least disregard, the rules for being good socialists. The accounts of middle-aged Russian women traders reflect the sense of rupture many experienced as Soviet state hierarchies of value around work and education became meaningless, and new, often contested hierarchies emerged. This process has parallels elsewhere, including across the former Soviet Union and other countries where, until the early 1990s, state socialist ideals officially defined relationships between individuals, and the state above all other institutions shaped the forms power took (e.g., Berdahl 1999; Dunn 2004; Leshkowich 2006). Significantly, these renegotiations of relationships between individuals and state power are also characteristic of newly global capitalism; the focus on emotion and affective states provides a means for reflecting usefully on the ways that intimate practices may intersect with processes occurring on a global scale.

Drawing on the narratives of three women-Olga, Galina, and Ania-who all began working as small-scale traders in the early 1990s, in this chapter I examine 


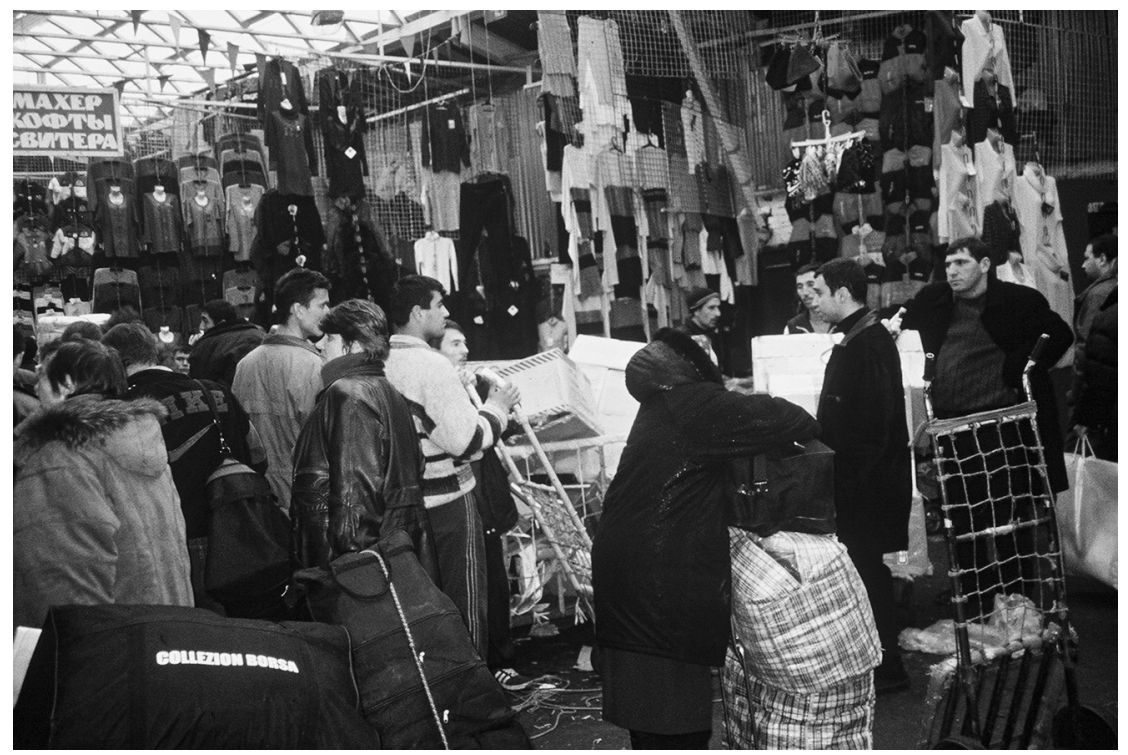

FIGURE 9. At a Moscow wholesale market. Photograph by author, 2002.

links between emotion regimes of late socialism and forms of gendered consciousness under emerging capitalism. In this economic landscape where the categories of capitalists and communists became blurred with the end of the Soviet Union (see Grant 1999) I consider how emotion work mediates women's insertion into a global economy. These entrepreneurs each have a unique background, including when and how they entered into trade, their levels of education, and the composition of their households in Russia. Nevertheless, like the fifteen other traders I formally interviewed and many I conversed with more informally from former Soviet countries, these entrepreneurs are linked through their experience of the shuttle trade, an artifact of the emerging post-Soviet market economy and an active category of economic activity within post-Soviet public culture. ${ }^{3}$ Furthermore, these women from Russia entered into the realm of trade in an era marked by abrupt ideological change; as Caroline Humphrey noted in the early 2000s, Russia, like other postsocialist locations, was "inventing its own new culture" $(2002,71) .^{4}$

\section{Shuttle Trade and New Forms of Labor}

"Shuttle trade" — which draws its name from the Russian word chelnok, or the shuttle that a weaver moves to and fro as she creates a piece of cloth-describes the small-scale business of moving consumer goods, and especially apparel, from 
global textile manufacturing centers into the FSU. Shuttle trade officially debuted with the passage of the Law on the Customs Tariff of the USSR in April 1991 (Stanley 1996; Humphrey 2002, 73). While this form of "small-scale" trade was not unique to the FSU (for example, see Konstantinov 1996), the scale of it alone makes it an important area of inquiry. For instance, in the mid-1990s, at the height of the shuttle trade from Turkey to the former Soviet Union, exports ran to $\$ 10$ billion annually (Yenal 2000,3 ), a sum that was possibly nearly half of Turkey's total exports at the time. ${ }^{5}$ By the end of the 1990s the shuttle trade had slowed, but it remained an important feature of mobility and trade in the region (Yükseker 2007; Weitz 2010).

From the perspective of the traders, the first years of international travel were imbued with novelty. Although people did travel extensively within the Soviet Union and some within the "socialist camp" of East European countries, the average person had never dreamt that it would become common to cross into Turkey or travel to Western Europe. My consultants fondly recalled their first journeys out of the former Soviet Union when they traveled to nearby Poland, Romania, or Hungary transporting household items, socialist-era lapel pins, or "cognac" (koniak) intended for resale (Hann and Béller-Hann 1998; Hohnen 2003). ${ }^{6}$ One woman, a former employee in an electronics factory, who began trading in 1993, described her sense of amazement when she first traveled to Warsaw by bus; the second time she took her daughter for four days, and they spent half the time exploring the city, eating Chinese food, marveling at the wellkept, beautiful churches, and visiting museums. Drawing on the travel agency offers of shoptur, package tours with all-inclusive hotel and travel arrangements that catered to traders, people like her often combined a few days' vacation with wholesale clothing purchases for resale back home. In addition to the excitement about crossing long-closed borders, however, these journeys were being made out of necessity. ${ }^{7}$

As Humphrey notes, by the mid-1990s, "Around 30 million people (41 percent of Russia's working population) were engaged in the international trade in petty commodities and services tied to that trade" (Nikitina 1996, cited in Humphrey $2002,73) .{ }^{8}$ Women and other marginalized populations, in particular, frequently turned to the shuttle trade or to working as vendors for shuttle-traded goods (Zhurzhenko 1999; Humphrey 2002, 90-93; Werner 2004). ${ }^{9}$ As the state abdicated its former role of maintaining government-run stores throughout the FSU, local "open-air" (otkrytye) markets expanded, with clothing imported by shuttle traders and other consumer goods, including tools and car parts, brought from Western Europe and Japan (via the Russian Far East). ${ }^{10}$ Although China may have been the earliest destination for shuttle traders seeking to supply Russia with clothing (Zhao 1994, 401), by the mid-1990s Turkey became the primary source 
country. The trade in apparel can be seen as a tangible reflection of Russia and Turkey's newly intertwined relationship from the early 1990s onward. In 1996 alone more than two million people from the former Soviet Union and Eastern Europe entered Turkey as "tourists," and most likely many of these were making trips combined with the goal of shuttle trade (Tosun 2001, 299). ${ }^{11}$

With a number of urban centers serving as important loci for shuttle trade from Turkey, Istanbul is by far the most important nexus for a wide range of financial, political, and international transactions, including the thriving garment trade (Keyder 1999). The garment trade is concentrated in the neighborhood of Aksaray and adjoining Laleli, just one tram stop beyond the main tourist area of the historic Sultanahmet, where the Topkapi Palace and Hagia Sophia are located. Since the arrival of shuttle traders in the early 1990s, Aksaray and Laleli are conjoined in the popular Turkish imagination as the "Russian" area of town, with restaurants displaying menus in Russian and featuring borsht and "Russian salad," Turkish hoteliers and taxi drivers speaking conversational Russian, and neighborhood kiosks selling Russian-language newspapers and magazines. ${ }^{12}$ Handwritten signs in Russian are taped to store windows and advertise for assistants who can "speak Russian and Turkish," or indicate especially for Russians, "We have large sizes." 13 In 2015 a prominently displayed digital sign in Russian offered migrants assistance in regularizing their status.

Like Olga, the woman I first accompanied from Moscow to Istanbul, shuttle traders arrive in Laleli on average bimonthly, staying for two or three days of intensive trade before returning with their merchandise to regions of the FSU. At hotels with names like Prestige and Paris, traders are met by staff who greet their return customers by name and remind them of the opportunities to take part in excursions around the city or to Black Sea beach resorts. Although Russianspeaking men from the FSU are sometimes encountered in this trade district, their sparse numbers make them conspicuous; moreover, it is women who seem to be most at ease in these trade spheres and who are obviously catered to by the overwhelmingly male, Turkish shopkeepers, tour operators, and restaurateurs (Yükseker 2004). As I discuss further in chapters 4 and 5, Turkish men and postSoviet women are frequently drawn into each other's worlds, sometimes through work but sometimes also through a desire for intimacy.

Yulian Konstantinov et al. (1998) suggest that among traders who were traveling between Istanbul and Bulgaria, women predominated because the shuttle trade was seen as a low status sphere of work. Also, they argue that men were more selective about where they were willing to work, and the authors associate both the retail market settings in home communities and the profession of trade itself with low status (Konstantinov et al. 1998, 739). This may in part explain the gendered nature of the shuttle trade between Russia and Turkey. However, it is useful 


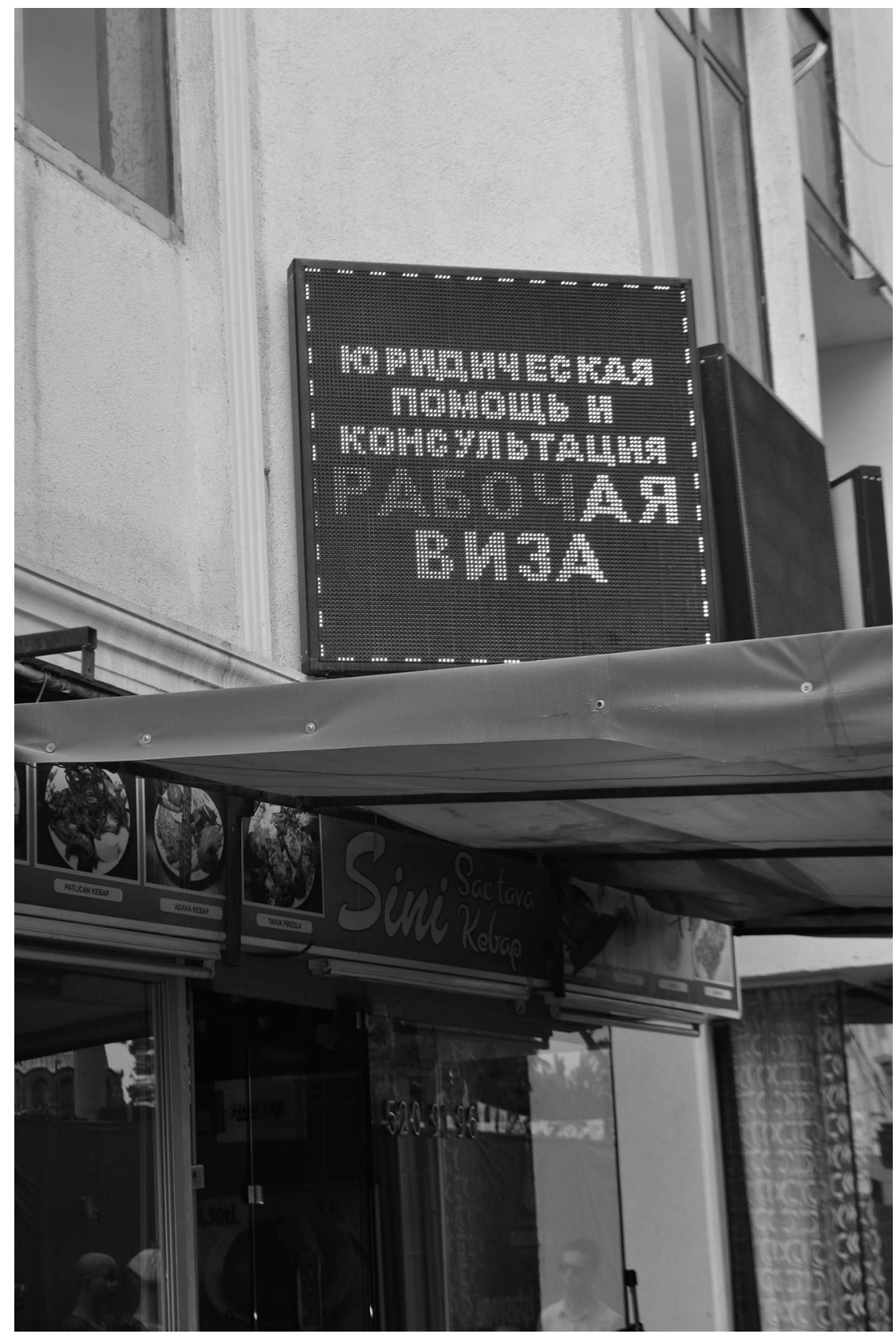

FIGURE 10. “Legal assistance and advice, work visas.” Photograph by author, 2015. 
to take this further and to consider how women navigate these issues of status. As a number of scholars have suggested for other types of work globally where "service with a smile" or emotional labor is integral (Hochschild 1983; Ehrenreich and Hochschild 2002), women tend to predominate. As Arlie Hochschild (1983) argues, in sites of firmly entrenched capitalist work relations, emotional labor is integral to a patterned yet invisible emotion system that consists of "individual" emotion work as well as a range of interactions between people in both public and private life. In the case of post-Soviet women traders, they are adept at navigating an invisible system of emotion work in the public realm of their dealings in Istanbul, where their hard-nosed business dealings belie any sense of shame about being entrepreneurs. Back home in Russia they navigate a different system of emotion work, in particular to allay anxieties about two types of shame: one shaped by Soviet sensibilities of proper labor and another one linked to reified models of masculinity, men as household heads, and domesticity.

The women traders I came to know frequently treated their experiences in Turkey as a foil for framing their own lives as "liberated" from male dominance. For instance, while there is a wide range of clothing styles worn by Istanbullu women-including short skirts, jeans and T-shirts, and headscarves—given the location of Laleli, bordering Fatih, one of the more religiously conservative neighborhoods of the city, traders often encountered women who signaled their identification with a growing Islamist movement in Turkey through wearing hijab. Clothed in the Tesettür fashion, or "Istanbul chic," of long, black coats and colorful headscarves and often accessorized with stylish footwear (White 1999, 80; Navaro-Yashin 2002), these women personified for the traders the "oppressed" Turkish woman. ${ }^{14}$ It was common to hear trader women murmur among themselves about how Turkish women are dominated by men, forced to "cover themselves entirely" (polnost'iu zakryvat'sa). At different times I heard trader women and entertainers invoke the same phrases- "It's not possible for them to breathe! There's religion for you!" (Nevozmozhno im dyshat'—vot tebe religiia!)—when encountering women possibly visiting from Saudi Arabia who were wearing fullface veils, such as burqua or niqab. Frequently post-Soviet women intoned that seeing Muslim women forced to wear such clothing proved that Turkey lacked "civilization" (kul'tura). Post-Soviet women's comments reflect both trader women's sense of cultural hierarchies and their lack of appreciation for how the widely circulating nationalist and Islamist discourses in Turkey, and elsewhere in the Middle East, get expressed through contests over women's proper gender comportment (Abu-Lughod 1997; Werbner and Yuval-Davis 1999; Parla 2001). Furthermore, however, post-Soviet women's comments foreground how trader women's own moral frameworks were forged through socialist ideals of 
modernity that hinged on their own distinct gender ideals, namely egalitarian gender relations and forms of labor.

\section{Markets, Gender, and Labor}

In their accounts of becoming traders, post-Soviet women entrepreneurs often articulated a sense of shame about the ways in which their new professions had forced them to make fundamental philosophical changes in their lives. In reflecting on their early years in the profession, they were keenly aware of moving away from a set of shared principles that grounded them as Soviet citizens; they frequently framed the newly capitalist society of Russia as one that was "degenerating." As in Nancy Ries's (2002) work focused on postsocialist narratives around money and morality, my respondents looked to the Soviet past to make sense of their experience of newly capitalist practices.

In interviews with traders they sometimes pointed to the years following the Second World War to explain the internalized idea of trade as a stigmatized profession in the Soviet Union. At that time, they told me, it was the women who often found themselves in such desperate straits that they were willing to risk fines and government sanctions just to provide for their families. With millions of men killed on the Western Front or imprisoned in the wake of Soviet repressions, women were left running households on their own. One woman told me how her mother was selling homemade quilts at a street market in the Russian Far East when she was arrested in 1946. She was accused of spekuliatsiia, or "profiteering," engaging in trade for private profit, and sentenced to three years in prison. Eventually the sentence was commuted and she lost one-half of her salary for three years instead of serving time. After that, my consultant recalled, her mother would always have to indicate on official forms, such as job applications, that she had a criminal record (osuzhdennaia). ${ }^{15}$

Experiences like these form the narrative backdrops for contemporary entrepreneurial activity, especially among an older generation of women traders. Women vividly recalled the dangers of trade in the past. Traders I interviewed expressed a range of reflections on their roles as "profiteers" (spekulanty), as they sometimes half-jokingly referred to themselves, thereby invoking a pervasive derogatory term from the Soviet era. Women traders' narratives on their new labor practices were interwoven with deep emotional reflections tied to the way in which work and proper forms of labor were understood. These cultural concerns are distinctively tied to the history of entrepreneurship (predprinimatel'stvo) in Russia (see Pesmen 2000, 126-45; Sasunkevich 2016). Grand narratives in the Soviet Union shifted over time and their weight differed depending on their location within the Soviet Union, but as Susan Buck-Morss (2000) and others (Bloch 
and Kendall 2004) have written, generally these grand narratives elevated the value of manual labor, the collective good created through socialism, and overcoming oppressive structures of capitalism. Traders' accounts turn our attention to how emotions around entrepreneurship were shaped by dominant structures of feeling defining Soviet and late Soviet society.

The scholarship on entrepreneurship widely focuses on an entrepreneurial ethic as something that is considered praiseworthy (for instance, see Weber 1958; Harrell 1985; Kapchan 1996; and Oxfeld 1999). However, turning to formerly socialist societies undergoing market reforms shifts this emphasis, underscoring the cultural contingency of the entrepreneurial ethic and the forms it takes. Entrepreneurship in the region of the former Soviet Union and Eastern and Central Europe has a particularly troubled history up until the late $1980 \mathrm{~s} .{ }^{16}$ As the quotidian Russian saying, "Don't have 100 rubles, have instead a hundred friends," suggests, trade and making money have had a historically ambiguous, and sometimes negative, value in Russia (Brooks 1985, 269-94; Pesmen 2000, $126-45) .{ }^{17}$ Still, some people did pursue private profit, even in the long period (late 1920s to late 1980s) when private enterprise was illegal and highly discouraged. Those who sought to profit from goods that were in short supply operated furtively with variable risk at different historic points (Sampson 1987; Humphrey and Mandel 2002). ${ }^{18}$ Although in the past state socialist economic ideals did not match reality, and a parallel, albeit barely tolerated, economy existed, in Russia in the early to mid-2000s for people of an older generation a link between entrepreneurship and "exploitation" persisted. For many, entrepreneurship was tainted by a view of entrepreneurial activities as possibly related to the mafia or as "unproductive" compared to other "socially useful" forms of work, such as being a factory worker or teacher (Dunn 1999, 133; Kaneff 2002, 35; Pine 2002a; Patico 2008). ${ }^{19}$

Both men and women participated in the widespread parallel economy in Russia under late state socialism, but women were perhaps more attuned to this economy given their long-term role in organizing and provisioning the household with basic necessities like food, clothing, and medicine, items that were obtained through networks, informal exchange, and the semilegal street markets (rynki) at least as often as through government-run stores (Bruno 1997; Mukhina 2014; Sasunkevich 2016, 154-57). ${ }^{20}$ In this sense, socialist ideals of labor, as something grounded in state production and fundamentally a part of nationbuilding and not related to a domestic sphere, were challenged on a daily basis by women. Nevertheless, as women traders' accounts in the next section indicate, they perceived their daily use of informal networks and exchange in their personal lives under late socialism as fundamentally different from what developed in the 1990s, when their professional lives became defined by involvement in 
trade. Under state socialism women were what Daphne Berdahl (1999) has called "worker-mothers"; they were officially defined in both a professional sense, as working for the state and building state socialism, and as shouldering the primary responsibility of caring for families. While state policy sought to mobilize women into the workforce and socialize the care of children and households, as I discuss further in chapter 6, this was far from fully realized during the nearly seventy years of Soviet power. Such official policies of gender equality were one of the first elements of socialism to come under attack in the popular culture of the late 1980s (Posadskaia 1994; Gal and Kligman 2000). ${ }^{21}$

By the early 1990s the gap between popular and official discourses around gender virtually disappeared. A new hegemonic discourse emerged with men's role as breadwinner elevated and women's ideal role situated firmly within the home. This discourse hinged on the idea that in empowering women with access to professional mobility, the socialist state had usurped male power (Kukhterin 2000; Kay 2006). Government policy that enshrines what some have called domostroika (Goscilo 1993), others the "new power of old men" (Thelen 2003), others the "retreat to the household" (Pine 2002b), and still others the "housewife gender contract" (Temkina and Rotkirch 1997) has emerged across former socialist regions, where women's space is now naturalized as a domestic one. In the first decade of the 2000s, the Russian government actively promoted this binary model of gender roles, most recently by instituting pronatalist policies meant to encourage women to have more children and to spend more years at home caring for them (Rotkirch et al. 2007; Rivkin-Fish 2010). It is in this context that women traders discussed the shame they experienced early in their careers, as well as the emotional labor they engaged in to maintain the semblance of "traditional" gendered divisions of labor in households, even as they sought to thrive in their work as entrepreneurs.

\section{Traders' Narratives: Shame, Entrepreneurship, and Gendered Labor}

Post-Soviet traders' accounts of entrepreneurship show how ideas of "shame" were often intertwined with negotiating new forms of labor and household gender roles. ${ }^{22}$ As markers of a post-Soviet legacy, these ideas around shame cross class and family backgrounds, albeit in uneven ways. The traders I consulted had a range of professional experience, including in hospital administration, academic research, medicine, and factory work..$^{23}$ My consultants were women in their late thirties and early forties, with school-age children; in their reflections they tended to frame their households as important sites for providing emotional and material support for their children. ${ }^{24}$ All three women whose accounts 
I discuss here-Olga, Galina, and Ania-began their careers as independent vendors selling goods at open-air markets in hometowns of Russia. Although all the women's narratives featured some element of shame related to their entry into the world of entrepreneurship, their accounts also reflect the way a socialist ethic about productive work and meaningful labor was by no means uniformly shared by all small-scale entrepreneurs in a postsocialist era. Women were negotiating the "emotion work" required in their households around gender and labor on several levels.

\section{Olga: Family Business and Preventing "Real Men's" Shame}

Traders often told of their initial mortification at being associated with "trade" (torgovlia). However, traders' accounts also frequently incorporated reflection on the ways in which their new professions brought them great satisfaction. These feelings of pride had to be delicately managed so as not to add to the sense of shame that the men in their lives often expressed about being unemployed or employed within their wives' businesses. In many cases, women's work in trade brought together two discourses on shame: one grounded in Soviet sensibilities of proper labor, and a second one grounded in contemporary gender sensibilities that elevated men as breadwinners, something I first learned from Olga in 2002, when I accompanied her on the PanUkraine package tour for shuttle traders traveling to Istanbul.

Olga described her first months as a trader in the early 1990s, saying, "I was really ashamed" (mne bylo tak stydno), and she recounted how she figuratively just "hid under the stall" (priatalas' pod prilavkom) where she was selling clothes shuttled from Turkey. Being involved in trade was something she never dreamt she would do-it was simply beneath her stature as an educated woman, happily married with two children. Only after Olga waited for months to no avail to receive a paycheck for her work as a hospital administrator, and her husband lost his job as an engineer, did she turn to selling goods in an open-air market in her hometown about 60 miles south of Moscow. She started in 1993, just two years after the government began to permit transborder trade and license the openair markets. Using small sums of money borrowed from friends and family, she began building up her business. She turned out to be an astute businesswoman. After seven years of shuttling low-end goods by train and bus from Poland and Ukraine for resale in the open-air market, she established a small boutique in the newly constructed mall located nearby. ${ }^{25}$

In our first conversation in her hometown in 2001, Olga described the "bustle" of being in business for herself as more interesting than her Soviet-era work as a hospital administrator. She also enjoyed meeting new people and being able 
to travel throughout Southeast Asia, Western Europe, and China. Most of all, however, she enjoyed what this business meant for her family. She was proud to have a "family business" (semeinyi biznes), and she was able to employ her whole family. Her husband took care of the transportation of goods, her teenage son was responsible for the bookkeeping, and her younger son in elementary school was learning the retail trade, as well as assisting with the store maintenance. Olga expressed her pride in being both a provider and a responsible, taxpaying citizen and explained, "I know that I create jobs and in this way I'm assisting the government, and on top of that I can help my family." Olga's justification of her profession in terms of "help" for her family (and country) perhaps points to her effort to downplay the pleasure she gained from succeeding in the very public realm of business. Also, by invoking help for family she was able to signify her connection to a domestic realm, an explanation similarly invoked by Russian women entrepreneurs in other contexts who also sought to justify their involvement in business (Bruno 1997, 63).

Olga's statements about her motivations to engage in entrepreneurship could be seen as interwoven with the status quo of power relations in her family; even if she was an entrepreneur, she was still signaling that the domestic realm was her primary responsibility. This form of negotiating on/around the domestic front was further substantiated in a conversation we had in 2002 after a day of wholesale purchases in Laleli. Olga and I sat in a restaurant at the Hotel Prestige and sipped mugs of beer as we took stock of what she considered an unusually fruitful trip. She had spent over $\$ 2,000$ in just three days, and she was content; she had been able to find affordable suppliers for the wholesale polo shirts, dress pants, and shoes for her second, newly opened boutique specializing in men's clothing.

Despite her satisfaction with the purchases, Olga said that she had to quietly enjoy her business success when she was home; her husband had been unemployed since 1996, when his government engineering division shut down. Generally he was supportive of her business; nevertheless, Olga said she needed to protect his pride. She not only tried to downplay her triumphs in business, but she also tried to avoid asking him to assist too much around the house or with looking after their younger son; instead, she often called on her mother for help. Also, when possible, she actively played up her dependence on her husband, for instance, by remaining unable to drive. She explained that her husband's monopoly on the driving would help her husband feel like a "real man" (nastoiashchii muzhchina) when she called on him to drive her around town and transport the wares she sent home from Istanbul. We finished our beers and Olga sighed, saying not knowing how to drive was a small price to pay for mostly having a smooth marriage and adequate economic means for the family. 
In a parallel way Carla Freeman (2007) argues that along with the new forms of labor people engage in as they are inserted into a global economy, they must also take on new forms of affective labor in domestic spheres. In her ethnography of women entrepreneurs in an increasingly neoliberal Barbados, Freeman shows that as new subjectivities around work emerge, these also shape the form "marriage partnerships" take. Like Olga, the Barbadian women entrepreneurs Freeman writes about sought to thrive in their business pursuits, in part, by drawing on relatively conservative and historically derived gender configurations. Women did not contest the forms of male power their husbands enjoyed, and they sometimes acquiesced to downplaying their own business successes in exchange for maintaining functional marriages which smoothed some of their business transactions.

Like the Barbadian women, Olga partly defined her successful entrepreneurship through the stable marriage partnership she was able to maintain with the emotion work she did to attend to her husband's need for validation as a household head. In this way, Olga's new form of labor was linked to affect that was forged by global economic shifts and new ideologies. Olga recalled her shame at taking on a profession colored by its vilification in the Soviet era but also expressed a sense of pride in having established her thriving business. This pride is then juxtaposed with her efforts to cope with her spouse's shame about being unemployed and more closely tied to a domestic sphere. While savoring her success as a transnational businesswoman, Olga safeguarded her husband from feelings of inadequacy by sheltering him from domestic responsibilities. This case provides a means for reconsidering the way moral frameworks, in this case around shameful labor, are negotiated when people are suddenly inserted into global capitalism; trade is no longer shameful, but long-standing codes of male honor, or definitions of masculinity, remain firmly in place, so in a post-Soviet context, new configurations of the relation between shame and trade emerge.

Post-Soviet women traders' concerns about shameful involvement in trade powerfully demonstrate the way discourses around emotion operate in a historically circumscribed way, a point scholars have made in other contexts as well (Wikan 1984, 648; Abu-Lughod and Lutz 1990, 5-6). In this case, attention to discourses on shame can teach us something about the way in which many people were defined by specific tenets of socialism. In traders' accounts the concept of "shame" is a productive category to explore since it puts individuals' relationship to an idealized Soviet citizen in relief. As Sara Ahmed writes, emotions themselves define boundaries of collectives $(2004,9-10,108)$, but they also point to spaces of negotiation. Attention to discourses around shame both underscores a "post-Sovietness" that continues to define the region and points to how the gender politics of households are shaped as they are inserted into global economies. 
Men like Olga's husband could feel shame about no longer enacting the role of provider as prescribed by dominant gender ideologies in late socialist and postsocialist Russia, and traders could feel shame as they entered a formerly illicit realm of labor because of how gender roles and the meaning around work shifted in late socialist society and later. The case of post-Soviet women traders vividly demonstrates how labor can be invested with particular affect and potentially experienced very differently by men and women, in part because they are unevenly inserted into a global economy. When traders' spouses feel shame because their ideal forms of masculinity are eclipsed by their wives' success, this is not simply a psychological process, but one reflecting how societal gender norms are being transgressed. Likewise, for women I interviewed the shame linked to entrepreneurship, exemplified by Olga's desire to "hide under the stall," was not merely due to a fall in social status. As demonstrated in the following account, social status was intertwined with the state ideologies marking trade as a suspect and morally tainted activity, but new forms of power (and powerlessness) were also refracted through the emerging emotion regimes.

\section{Galina: Laboring for Socialism and the Shame of a "Social Parasite"}

Unlike Olga — who after seven years of selling clothing in the open-air market garnered enough capital to rent space in the nearby indoor mall for her own boutique-most women working as vendors in the former Soviet Union in the 2000s did not have the financial means to rent retail space or make regular treks to Istanbul (or other centers of apparel production and distribution, such as Harbin, China). Instead they retailed goods sourced from established wholesalers within Russia. This was the case with Galina, a woman I met in 2001 who had shared a market stall with Olga during her early years of entrepreneurship in the same small city south of Moscow. Galina remained working as a vendor without much possibility of "classing up," but she shared some of Olga's sense of shame associated with her work as a trader. ${ }^{26}$

Until 1993 Galina worked full-time in a building materials factory in the section where two huge cauldrons were constantly fed to make steel. By 2000 the factory had shut down, and Galina had begun cobbling together income, in part through selling wares she purchased in Moscow. In 2003 Galina lived with her fifteen-year-old daughter, who was training to work as a technician in the dairy industry, and her ten-year-old son in a detached house on a small plot of land she had inherited from her parents. Her husband had died years earlier. She occasionally met with her lover, a construction worker on contract from Bulgaria, 
but he did not contribute to the household, and by 2003 she had supported her children single-handedly for nearly a decade.

Galina was significantly less successful at trade than her friend Olga. The main difference between the women was Galina's lack of capital. Although Olga was able to build her business through the social and financial capital of her friends, family, and professional network, Galina had no similar sources of support. She was forced to supplement her meager income, and in 2003 she first sold one of her goats and then began selling prepared lunches to the other vendors at the market. A passionate singer, Galina sometimes made extra cash by taking on jobs singing at wakes. Even after more than fifteen years of trade, however, she was not able to establish enough capital to move from the open-air market to a space in the nearby mall.

Despite their disparate social locations, Galina's narrative echoes some themes raised by Olga. Galina spoke vehemently about how difficult it was at first to trade at the market. She recalled how people would practically spit on vendors. The woman renting half of Galina's stall in 2001 was a teacher until the early 1990s, and she would hide when she saw former students or their parents approach her stall. Like the former teacher, Galina recalled how, when she began trading in the market, she also wanted to hide behind the stall, avoiding anyone who might recognize her. As she explained, "I felt like a tuneiadets." In invoking this Soviet-era term for a social parasite, or a person who does not engage in productive labor, Galina emphasized that to be a trader was to be a fallen socialist of sorts. ${ }^{27}$

Galina reflected on how life had changed since the end of the Soviet Union. She lamented that most people only had the markets as a source of income now and that this type of work and social milieu changed people. As she explained, "They become uncultured and lose sight of what matters-social interaction, music, and relaxation." Galina recalled how, as part of her benefits as a factory worker in the Soviet era, she could travel each year to vacation on the Black Sea for a month; since the late 1990s she could not save a penny, and a vacation of any length was not possible. She was barely able to pay for her household's food and clothing needs. There was little time, money, or energy left for what mattered in the past. As another woman at the market noted,

[Under socialism] the system was really wrong; it made people fit all into one type. If you have a row of plants growing and some grow taller or fuller than others, these had to be trimmed; everyone had to be the same. We were limited by this system; we were confined to one way of seeing the world.... But then the system also looked after everyone; you didn't have to pay before being treated in the hospital; everyone had 
access to the same day-care system; there was food and housing. True, some people got better things, but no one was left without.

Another woman standing at a nearby stall one day chimed in, "We worked hard in those days, but we were cared for ... I gave my life to the factory and now they abandon us."

Comments like these reflect a widespread sense of how an allegiance to a social system with all its flaws was built up over time. Like any society, the Soviet Union had a set of grand narratives that were familiar to its citizens, and these included the common suffering during the Second World War, the way the state provided for all, and a clear common enemy_capitalism (Buck-Morss 2000). As a number of scholars have noted, among the less fortunate in a postsocialist era, these allegiances and deep-rooted nostalgia for socialist society tend to continue; in the first decade of the 2000s it was also not uncommon for a wide strata of the population, and especially older people, to wish for the stable lives they sometimes associated with Stalin's era. ${ }^{28}$ The desire to hide beneath the market stalls was a by-product of a system that officially placed societal well-being above private profit. The fact that women entrepreneurs recounted these intense initial feelings with such vehemence even ten years after they entered the realm of trade demonstrates how they struggled to reconcile discourses of a market ethic that elevates entrepreneurship as socially desirable with deeply resonating discourses of a socialist era.

\section{Ania: Capitalism and the "Devolution" of Society}

Both Galina and Olga's accounts highlight a widespread sense of initial ambivalence or even antipathy toward the new market practices in which they became involved, but a few women expressed no such conflicted feelings. One woman I met in 2007 during her weekly buying trips to Istanbul described her decision to become a trader as a carefully calculated decision, largely tied to the need to find adequate housing. During a short break from her purchasing, Ania insisted on treating me to Turkish coffee, and she readily narrated how she came to be a trader. Until 1993 Ania had worked for ten years as a microbiologist for a research institute in Moscow. She emphasized that when she decided to leave the institute she was fairly established and had been publishing her work in well-regarded journals.

Ania described how in the early 1990s, as many people in Russia were being laid off, her husband quit his job at the microbiology institute and began engaging in the shuttle trade to Poland. Ania soon followed in his footsteps, leaving her job when it became obvious that the institute would not be arranging an apartment for her; the couple had lived in a two-bedroom apartment with her 
parents for nearly ten years. By 1994 Ania and her husband had established two stores in Moscow that Ania continued to supply in 2010 by traveling once a week from Moscow to Istanbul, often spending as much as $\$ 10,000$ on wares in a single trip. She recounted that, despite her success at being a trader, the transition from being an academic was not easy; Ania said she had earned each dollar of her original start-up capital by standing in an open-air market selling her wares day after day, rain or snow.

The decision to leave her academic job was something Ania regretted in some ways and as she explained, "I left the world of ideas for the world of money." Ania described what she saw as the "slowing down" of human civilization; she equated the onset of a postsocialist, newly capitalist society with a sort of "devolution" of former socialist societies wherein education and learning had become relatively unimportant. In looking back at her decision to change professions in the early 1990s, Ania ruminated: "I'm not sure I would make the same choice again. When I ask myself from a philosophical and moral perspective-not from a marketdriven one-this has been a very difficult life.... Something had to break down in my consciousness for this business life to work. In fact, for nearly five years my mother was ashamed of me because of my work."

Ania's parents were also academics, working in the same institute as she had, and Ania explained that her parents differed in their views on her new profession. Ania's mother was ashamed that her daughter would leave an academic life for one that had so much stigma attached to it, but she did agree to look after Ania's son during the regular trips Ania made to Istanbul. Like Galina, Ania sought out emotional support from her mother to smooth the regular operation of her business; neither of the traders' husbands was willing to take on the household work around caring for an elementary school-age child in their wives' absence. As Ania explained, without these care arrangements, her husband would never have agreed to her absence for days at a time each month.

Ania's mother only gradually changed her mind about her daughter's new profession as she saw how much better Ania could provide for the household through her business. Ania said that she herself had not felt any sense of shame when she began the shuttle trade. As she explained, "Money changes people, not [new types of] labor [trud]." Responding to my comment that a number of my consultants recounted feeling ashamed about entering the sphere of trade, Ania scoffed and then added,

They were probably not entirely telling the truth; everyone likes money. Or else, maybe it is a matter of age, after all, my mom was also anxious about this business; ... not everyone relates to money in the same way. When the iron curtain went up people scrambled to come here to buy 
up goods ... and it changed people.... Everyone thought the good life had arrived; you could bring in just about anything [to Russia] and sell it without taxation. Everyone fed at the trough [obzhirali].

Ania's reflections suggest that the early 1990s was a time of major ideational disjuncture for many, but particularly for people involved in entrepreneurship. Her comments also emphasize the "emotional labor" that is particular to capitalism, wherein "invisible" labor goes into the relations performed in work settings and prospects of financial gain can change how people interact (Hochschild 1983).

Unlike Olga and Galina, Ania did not express any memory of her own shame about her enterprise; she presented herself as having a no-nonsense, hard-headed approach to her work. One might link this difference to the fact that Ania's business, primarily as a wholesaler of men's clothes manufactured in Turkey, was on a decidedly different scale from Galina's work as a vendor in an open-air market or Olga's boutique in a new mall. Ania's level of education, however, also sets her apart. Her investment in the Soviet project was not the same as that of the average Soviet citizen, and one could argue that as an academic she entered the realm of trade from a position that was more critical of the Soviet project.

Like many of the Russian intelligentsia Alexei Yurchak (2003) writes about, Ania was able to leverage her social capital to successfully navigate through the tumultuous end of the Soviet Union. Especially in contrast to Galina, Ania's material circumstances improved significantly in the ten years after the end of the Soviet Union, and this prosperity very likely overshadowed feelings of nostalgia she might have had for socialism. Still, like the other two women, Ania reflected on the fundamental changes she experienced in her sense of self in the newly capitalist Russia. In speaking of the "breakdown of consciousness" she underwent in entering the world of trade, Ania signals how socialist structures of thought shaped her inner world in the past, and how becoming a trader required a type of emotion work.

In many ways Olga, Galina, and Ania share a common sphere of experience, even an emerging consciousness of sorts. Their concerns, desires, and aspirations intersect in significant ways. They continue to share a sense of place, including sometimes a sense that they were betrayed by a system that they paid into. All three of these women and their professions as traders are linked to a global economy, primarily through Turkish-produced apparel which they sell to Russianspeaking populations with a history inflected by Soviet state ideologies. Finally, as post-Soviet women in their forties at the time we met, all of them had their sense of self as workers and members of society shaped by a Soviet legacy; they are very much members of what Alexei Yurchak has called "the last Soviet generation" $(2003,486)$. This last Soviet generation is also the first newly transnational 
generation of people on the move out of the former Soviet Union, and the first doing the emotion work in public and domestic spaces that is required to navigate their households' integration into a global economy.

Affective labor may be a key aspect of contemporary global capitalism, but it is not just managed by political or cultural formations; people like Ania or Olga or Galina also actively make decisions about how much to invest in it. The "managed emotions" of capitalism (or state socialism) are part of specific hegemonic projects, and people have variable degrees of desire to embrace or resist these, or simply ignore them. In paying attention to these emotions we can denaturalize any sort of "transition" or natural progression from socialist to capitalist forms of society and, instead, we can see continuities, frictions, and interconnections. Pointing to the role of emotion and affective states in Russian entrepreneurs' experiences of becoming traders destabilizes some commonsense ideas of capitalism as a liberating force in the region or socialism as simply oppressive, but most important, it creates openings for better understanding how gender, intimacy, and new forms of mobility come together in this area of Eurasia. 